\title{
Personal Urbanities: Domesticating the Public Domain
}

\author{
Jacopo Leveratto \\ Politecnico di Milano
}

\begin{abstract}
City and personality have never been easily associated. Historically, since classical antiquity, urban space has always been the reflection of a collective identity representing the natural inclination of human beings to live in group. However, according to Lewis Mumford, the city has been the context in which another ideal arose-the concept of personality. This ideal, according to the official history of urban design, seems to have had a very marginal role, if not as a formal or functional analogous structure. Nevertheless, looking at the physical consistence of built space —as well as its ideal formulation —it is not difficult to find some evidence of Mumford's theory. Therefore, the paper, through an architectural overview ranging from classical street-side benches to contemporary digital cities, aims at outlining the progressive change in the representation of urban identities from a collective to a more personal dimension. It describes how public space design, especially during the last 30 years, has redefined its strategies in order to increase the possibilities of personal intervention for users, and it focuses on the gradual shift of this discipline towards other scales, instruments and objectives, in a sudden disciplinary convergence with interior architecture and industrial design. Thus, showing how a pervasive process of domestication is nowadays transforming not only the use, but also the symbolic meaning that the public domain has traditionally had.
\end{abstract}

Keywords: architecture, urban image construction, identity creation, public spaces, human scale

\section{Introduction}

From a spatial perspective, city and personality have never represented commonly associated terms. Historically, since classical antiquity, urban space has always been considered the reflection of a collective identity representing the natural inclination of human beings to live in group (Aristotle 2012, 25-28). Its millenary evolution has always taken place within a sort of organic "collective horizon" (Benevolo 1993, 10) through which Greek civilization made the urban form coincide with its social body, so that today the term urbanity indifferently refers both to the physical features that make a city recognizable and to the ideals of civil coexistence.

Nevertheless, even though the collective nature of urban structures is hardly deniable, according to the great sociologist Lewis Mumford, the city has been the context in which another apparently conflicting ideal arose - the concept of personality $(1961,107-10)$. His theory, which follows with the birth of private property, is detailed and complex, but perfectly consistent. In Mumford's view, private property did not begin, as Pierre-Joseph Proudhon believed, with the theft, but by considering the common heritage as a personal property of the king. Once this principle was accepted, it was possible to alienate the property of the State and subtract it

Jacopo Leveratto, Ph.D. Architect, Adjunct Professor in Interior Architecture, Department of Architecture and Urban Studies, School of Architecture Urban Planning and Construction Engineering, Politecnico di Milano, Italy; main research fields: Architecture, Urban Design, Human Scale, Public Sphere, and Everyday Practices. 
from the community, through the king's personal gift. With his political gesture, the monarch began to distinguish a series of individualities from the social body that started to acquire some of his privileges, including that of being considered persons and no longer part of a collectivity. Thus, the city became a "special environment... for making persons... the chief agent of man's transformation, the organ for the fullest expression of personality" (Mumford 1961, 110).

Therefore, in Mumford's view, the city - with its hierarchical, differentiated, and specialized structure - does not represent the spatial crystallization of a communal organism. It rather constitutes the venue in which the pre-urban collective ideals have progressively faded in favour of a much more "personalistic" social construct. In this sense, urban space seems to be the physical location of an incremental "process of individualization" which characterizes the very idea of modernity. Here, the concept of personality gradually emerges as a corollary of a progressive liberation of the individual from the "naturalness" of the social ties that marked the traditional forms of communal association (Tönnies 2001). In other words, the artificiality of the interpersonal ties that cities in their complexity require entrusts individuals with the task of their definition (Simmel 1976), compressing their identity within the last natural dimension still possessed-the personal one-which becomes the raw material of modern social constructs (Bauman 2000).

However, looking at the history of urban design since its origins, this aspect seems to have had a very marginal role in the real construction of the city, if not as a formal or functional analogous structure. The Western civilization, in developing its urban structure, seems to have strictly followed a classical tradition that simply ignored the personal dimension of the public realm. In fact, historically the design of urban open spaces had to follow one simple rule, established by Vitruvius in a short paragraph of the fifth book of De Architectura. Squares, just like theatres, had to be sized according to the maximum number of spectators of the gladiatorial games, or more precisely to their "multitude" (Vitruvius 1584, 208). For ages, the only indication about public space design concerned its users identified as an organic "audience.” There was no place, at least in theory and planning, for single individualities, and this lack implicitly became one of the constitutive disciplinary features of a particular kind of project that seems to have known very few variations along the centuries.

Nevertheless, looking at the physical consistence of built space—as well as its ideal formulation—it is not difficult to find some evidence of Mumford's theory. Furthermore, today this evidence seems to rapidly grow in number, informally defining a new approach towards open space design. Therefore, the paper, through an architectural analysis focused on the personal measure of public spaces, aims at outlining the progressive change in the representation of urban identities from a collective to a more personal dimension. It describes how modern public space design, especially during the last 30 years, has redefined its strategies in order to increase the possibilities of personal intervention for users, and it focuses on the gradual shift of this discipline towards other scales, instruments, and objectives, in a sudden disciplinary convergence with interior architecture and industrial design. Thus, showing how a pervasive process of domestication nowadays, following an incremental process of individualization, is transforming not only the use, but also the symbolic meaning that public space has traditionally had.

\section{Public and Personal}

As well as a progressive process of individualization is inherent in the idea of modernity, the specific focus on the human and personal aspects of public architecture, although implicit, has marked the modern urban development since its origins. The idea of modern city, presented by Leon Battista Alberti to Pope Nicholas V 
in 1452, did not arise as a simple aggregate of buildings, but represented a set of principles, policies, and actions, through which individuals played the role of the main character (Choay 1980). This took the shape of a continuous inhabited landscape that-interpreting houses as small towns and cities as big houses-effectively assumed the personal experience of urban spaces as the subject for an architectural project that knew no differences in scale (Alberti 1989, 36). Therefore, from Pienza to Rome, in less than a century, this continuity characterized the first integrated projects of open spaces based on the recovery of classical urban devices, which began to materialize the individuals' personal sphere in public design. ${ }^{1}$ In these cases, the initiatives were still private and the interventions were limited to the modulation of street-side benches at the base of some noble palaces. However, through an ineluctable reference to the body's extent, each one was capable of representing a personal attempt to inhabit the city—to physically re-appropriate its public dimension—which had to wait three centuries to find a definitive explanation. In fact, with the Counter-Reformation and the subsequent establishment of national states, the human dimension of urban constructions was largely neglected in favour of a representative spectacularization of power persuasiveness, reflected by a strict geometric regularity and a first functional specialization (Choay 2003, 54).

Since the second half of 19th century-with the first urban repercussions of the Industrial Revolution and the birth of new systems of street furniture (Carmona 1985, 6) - the perspective on the human dimension of cities opened up in a more physical and bodily sense. While the development of modern anthropometry was replacing the Neoplatonic ideal of man with a statistical model that could serve as a concrete design reference (Teyssot 2013, 45-49), August Schmarsow (1894), together with the historians and philosophers who belonged to the school of "Empathy," worked out a first spatial interpretation of architecture, of which body represented its phenomenological centre. Thus, the same criterion pushed Hermann Sörgel, 20 years later, to deduct for direct consequentiality an extension of this projectivity to all the urban figures who "have been drawn up by a spatial thinking” $(1918,51)$.

Yet, the personal traces of dwellers made their appearance within the project of urban space long before Sörgel's lesson, and precisely in the metaphorical image of a snowy field dotted with people's footprints that Camillo Sitte used to explain the spatial arrangement that characterized most of the Roman, medieval and Renaissance's squares. ${ }^{2}$ In the extent of these traces that structured "by difference" the conformation of urban open spaces, Sitte first recognized the role that citizens' personal bodies had in the construction of the real city—a city reflecting not only an organic collective body, but also a multitude of individual bodies shaping it with their actions, their social rituals, and their personal habits.

However, the vision of Sitte, characterized by an aesthetic and historicist nostalgia, has been isolated, when not explicitly mocked, for a long time (Le Corbusier 2007, 90-100). Until the mid-forties of the 20th century, as part of the housing emergency investing Europe after the World Wars, any attempt of body-based spatial standardization was implemented only within domestic environment (Gropius 1924; Neufert 1936). Contrariwise, cities-from the Ville contemporaine de trois milions d'habitants presented by Le Corbusier at the Salon d'Automne in 1922, to the "CIAM Grid" formulated 11 years later-represented the context of an aesthetic and functional utopian radicalization of the ideals of specialization and sanitation born with the first zoning experiments about the half of the previous century.

\section{Human Scale at the Core}

Something began to change during the 1950s, with the designers' first attempts to increase the responsivity 
of public spaces focusing on the human dimension of architecture. The best opportunity emerged in 1951, with the eighth Congrès Internationaux d'Architecture Moderne, dedicated to defining the real consistence of the "heart of the city" - the prerequisite of an authentic urban condition. In fact, even though seven years earlier Josep Lluis Sert had published an essay entitled "The Human Scale in City Planning” (1944), it is only during this conference that this concept began to have a clear meaning. ${ }^{3}$ Thus, since the mid-1950s, a growing part of the disciplinary culture started to focus on the identification of the relationship between physical space and people's socio-psychological needs, allowing architecture to reflect the different social and cultural patterns in a more accurate way (Smithson 1957). In other words, as an alternative to contemporary cultural and design criteria, urban, architectural, and industrial designers started to look for intermediate spatial solutions_-between public and private, collective and personal—capable of reaffirming an architecture that did not impose precise models, but was able to learn from any situation (van Eyck 1962).

Suddenly, in some of the most relevant projects of this period, public spaces ceased to be a uniform and undifferentiated field and became an uninterrupted series of intermediate places shaped on the measure of their personal use, capable of reflecting the real measure of human scale. ${ }^{4}$ Thus, in a short time, the polyvalent articulation of their margins, which functionally and symbolically accommodated both individuals and crowds in an organic and adaptable shape, ended up affecting a consistent part of the international architectural practices. ${ }^{5}$

From this premise, the 1960s became the time of a definitive spread of the concept of personal space within urban design. On the one hand-thanks to the contributions of Robert Sommer (1959) and Edward T. Hall (1966) — environmental psychology approached urban geography and reached a more conscious public space design, capable of overcoming those "urban pathologies" that, by overcrowding and isolation, may result in interpersonal violence. On the other hand, urban geography—in a clear reference to Robert Park and Ernest Burgess' school of urban social ecology—addressed the psychological and perceptual outcomes of the physical form of urban space, culminating with the publication of the essay by Kevin Lynch, The Image of the City (1960). Hence, the theory followed a dual path. A first one-from Jane Jacobs's conceptual proposals (1961) to Christopher Alexander's operative indications (Alexander and Poyner 1970)—-tried to define some concrete tools, such as density or functional mixture, for pushing individuals towards the centre of urban planning. A second one - thanks to the French sociological studies (Chombart de Lauwe 1952) and the first artistic experimentations of the Situationist International (Debord 1961)—represented the core of a political strategy aimed at the personal and collective "reappropriation" of the city (Lefebvre 1968).

Simultaneously, while design and planning began to reject the association of the urban form with an artistic phenomenon in order to highlight its fundamental social and human factor (Jarvis 1980), interior architecture-particularly in the Netherlands and Italy—focused its attention on the concrete tools capable of making the city "inhabitable" (van Eyck 2008, 51; De Carli 1967). Therefore, it is not surprising that, in these years, design investigations about urban open spaces were broadening and shifting from the mere articulation of their boundary surfaces to the definition of flexible or adaptable equipment, which could be used to transform the spatial arrangement according to the users' actual needs. ${ }^{6}$

Through the study of this equipment, in the following decade, different architectural researches seemed to specialize, focusing their attention on the real public consistence of personal space. Thanks to the contributions of Jan Gehl (1971), William Whyte (1980), and Kevin Lynch (1981), the interest of planning and urban design moved towards the construction of "responsive environments," considering within the design process the 
possibility of "spatial personalization," through the study of the relationships between the shape and the equipment of open spaces in their most concrete issues - such as the quality and location of seating, the articulation and the permeability of their margins, or the potentialities of visual openings. At the same time, architectural design — and in particular the Dutch structuralist school—starting from the study of the spatial claims that were implicit in the simplest daily practices, led the discussion on open space design beyond the criterion of representativeness that squares have always had to meet, to focus on a series of elements traditionally considered completely negligible (Hertzberger 1973). This specific attention to the architectural potentialities of accommodation implied the definition of a measure capable of accepting people's "gestures," in an almost total integration between shape and equipment that, unfortunately, had no time to sediment.

In fact, during the same years-and particularly since the exhibition curated by Emilio Ambasz for the New York's Museum of Modern Art, entitled Italy: The New Domestic Landscape (1972)—a new idea about the relationship between public and personal made its way, challenging the same principles of this integration with a sort of mobile and delocalized way of inhabiting which, in a short time, became really pervasive. ${ }^{7}$

\section{From Delocalization to Domestication}

During the last 30 years, increased possibilities of individual mobility, the exponential growth of information technology, and a progressive crisis of representation of social institutions have prompted new urban projects characterized by an incremental "disintegration” of the relationship between public and personal, in the form of a growing de-contextualization. From the first Archigram's experiments to the Japanese school of Toyo Ito, personal space design has been atomized, in a search of mobile living units unlikely intended to reinterpret the city, but rather to exploit it, using its facilities for a moment of leisure. ${ }^{8}$ Thus, in front of this spatial individualization, urban architecture seems to have had the only task of leaving space to "spontaneous events" (Derrida 1987), through a project giving the city the power of an iconic and stable image, and simultaneously the programmatic openness reflecting the multiplicity of uses that contemporary metropolis would have required (OMA, Koolhaas and Mau 1995, 515). From this point of view, the unusual size and the formal abstraction of these interventions - together with the absence of any functional definition and spatial articulation—nowadays are part of an international lexicon which admits very few variations. Their common feature consists in claiming a real separation between their shell, which needs to communicate the urbanity of a synthetic image, and the space enclosed, intended as a free and homogeneous field, in which the idea of a human scale seems to be materialized only by the infinite possibilities of choice that this "spatial redundancy" should offer but that, more often, are crushed by this indefinite openness (Spuybroek 2005). ${ }^{9}$

However, during the 1980s, this search for interpretable architectural shapes aimed at encouraging a personal engagement with space generated a different strategic approach for public spaces that, in less than ten years, defined a real design movement. With their first interventions of public art, the likes of Richard Serra, Daniel Buren and Vito Acconci showed how the physical and symbolic subversion of people's urban experience could bring them to question the very nature of their everyday environment, interpreting it in a personal way. This involved a clear articulation of polyvalent elements as well as the definition of a new architectural language that is still predominant. ${ }^{10}$ Mobile and interactive terminals, sinuous surfaces, bright colours and, more generally, a formal repertoire deeply influenced by visual arts, industrial design, and digital graphics reflect the character of a sort of "playful modernism” (Mosco 2010, 180), through which any participatory possibility is resolved in a form of uncommitted game. In other words, they highlight an approach 
based on a spectacular form of personal involvement with public space, meant to arouse curiosity, surprise, and also uneasiness, which in a few years has concerned a whole series of minimum projects designed to reinterpret the city. ${ }^{11}$

In fact, in the second decade of the new millennium, along with playground, house has made its appearance as a typological and spatial reference, progressively identifying the public sphere not as separate from the private dimension, but rather as an extension of the process of inhabiting that does not seem to meet any differentiation. As in their own homes people are free to create their own spaces by modelling a kind of interior "shell" made of objects, the same possibility is offered them outside thanks to the definition of a concave and hospitable place that uses a formal and functional repertoire recalling in every way the architecture of a domestic space. Thus, in a series of contemporary public projects, the house becomes the ultimate symbol of an interpretative flexibility that, today, seems to be required by the whole urban space (Klanten et al. 2012, 216-49). ${ }^{12}$

\section{Personal Cities}

During the last 20 years, as a result of technological improvements, a gradual anthropological transformation has started pushing the act of inhabiting beyond the boundaries of privacy, and the planned, organized, and symbolically characterized space of the city, with the inclusion of citizens' domestic spheres, has exploded into a plurality of uses and meanings. The urban topography no longer appears codified into clear patterns capable of establishing objective positional values, but it is continuously redrawn according to individual needs, points of view and habits. As in the individual house the functional organization of the spaces can be subverted and reassembled by a single person, today, in the experience of metropolitan territory, each person can trace their own "map." Thus, urban spaces reproduce, on a larger scale, forms and mechanisms of domestic interiors, in an "interiorized," "personal," and variable dimension that drives design disciplines towards a gradual overlapping of distant traditions (Leveratto 2014, 91). While interior architecture is trying to overcome its traditional spatial domain to face the public or semi-public spaces of metropolitan life (Basso Peressut 2010), urban planning attempts to interpret and map the "swarm" of spatial practices that seems to structure the city through a continuous process of personal re-signification. ${ }^{13}$

Today, this sort of disciplinary integration involves both a significant change in scale and a new way of looking at the morphogenetic mechanisms of urban projects, from a series of sequential operations-from a larger to a smaller scale- to a simultaneous process in which various decisional agents interact to generate a complex spatial system. Each strategy attempted by architects, designers, and artists in order to enhance the personal dimension of urban space has moved the conceptual centre of design from its margins to its "interior," in a substantially projective process of formal definition. Despite the existence and the recognisability of a circumscribed space are always relevant in this process, its formal quality seems to lie not so much in the geometric construction of its perimeter, but in its articulation in fields and objects that can be recognized, employed, and personally modified—in a word, "inhabited" in a direct and non-mediated way. Therefore, more than the urban morphological matrix, central to such projects is the degree of integration or mobility of that articulation, its exclusivity or its openness, its strictly symbolic connotation, or its interpretative flexibility (Leveratto 2015, 11).

However, this emerging design approach does not only involve a disciplinary redirection. It also pushes the process of urban image construction to a gradual shift of interest from the shape of space to the different 
forms of its "use" - to the many opportunities for personal appropriation that the architectural construction allows and encourages, both functionally and symbolically. In drawings as well as in stone, movements, practices, and personal actions of those who use the space become part of a project that shows in its own structure their traces and their ability to shape a place that they own and to which they belong at the same time. In these cases, urban space develops, as a domestic interior, around the "gestures" of the subjects who inhabit it, in a dimension in which the possibility to exert a real control on their environment is explicit, even though only symbolically. Thus, showing how the collective representativeness that public space has traditionally had to materialize is gradually fading in favour of a new idea of urbanity-a subjective identity that is not imposed or inherited, but can be imagined, built, and modified in the most absolute autonomy.

\section{Notes}

1. This respectively refers to the street-side benches surrounding Pienza's main square, designed in 1462 by Bernardo Rossellino, and Piazza Farnese's giant niches, designed in 1535 by Antonio da Sangallo and Michelangelo Buonarroti.

2. Noting that in many cases the place of fountains and statues seemed to challenge any principle of axial symmetry, Sitte tried to explain the choice through a simple comparison with everyday life. Trying to imagine a square of a village covered by a thick blanket of snow, it is possible to notice how, among the pathways informally traced by the footprints of passersby, there are some irregular areas of untouched snow. Here, away from traffic, just like children build their snowmen, the ancients determined the position of fountains and monuments (Sitte 1889, 24-25).

3. The same concept to which Sigfried Giedion, called in 1957 by Sert to the Graduate School of Design at Harvard University, dedicated a series of workshops on urban design.

4. See Le Corbusier's roof terrace of Marseille's Unite d'Habitation (1947-52) and Aldo van Eyck's Bertelmanplein (1947).

5. From Louis Kahn’s Salk Institute Plaza (1959-65) to Paul Rudolph’s Boston Government Center (1963-71), from Gio Ponti's De Bijenkorf Plaza (1969) to Richard Meier’s Twin Parks Plaza (1969-74).

6. See the first attempt made in this direction by the landscape architectural firm Zion \& Breen for Paley Park’s design (1967), a public pocket park located in a Midtown Manhattan's infill lot.

7. Significantly, almost all the environments presented at the exhibition, designed by authors such as Mario Bellini, Superstudio and Ettore Sottsass, involved an idea of domesticity that has nothing in common with the architectural definition of a house (Ambasz 1972).

8. See Mike Webb’s Cushicle (1966-67) and Suitaloon (1968), or Toyo Ito's Pao1 and Pao2 (1987). Today this line of research is carried out by such authors and firms as Micheal Rakowitz or Raumlabor, with a social connotation completely ignored by their predecessors.

9. See the Johann Otto von Spreckelsen’s project for Paris’ Tête Défense (1982) and the Albert Viaplana, Helio Piñòn e Enric Miralles' one for Plaza de los Paìses Catalanes in Barcelona (1983). Even today this strategy is widely used, as pointed out by the recent projects of Jürgen Mayer H. Architects and Pino Paredes for Sevilla's Metropol Parasol (2010) and Cordoba's Center of Civic Activities (2010).

10. This approach is clearly visible in a series of interventions ranging from Bernard Tschumi's Parc de la Villette (1983) to West8's Schouwburgplein (1991), from Pipilotti Rist’s City Lounge (2005) to BIG's Superkilen Urban Park (2013).

11. For a complete recognition, see Klanten and Hübner 2010. Here, it is worth mentioning the works of artists and designers such as Michael Rakowitz, Jeppe Hein, Damien Gires, Florian Riviere, Oliver Bishop-Young, DUS Architects, Heri \& Salli, and Oh. No. Sumo.

12. See Raumlabor’s Open House (2010), SABA’s Children Corner and Collectif Etc.'s Place au changement (2011).

13. See, among others, the recent experiments concerning "Space Syntax," "Swarm Urbanism," and "Real Time Cities" (Hillier and Hanson 1984; Leach 2009; Ratti 2014).

\section{Works Cited}

Alberti, Leon Battista. De re edificatoria. Milan: Il Polifilo, 1989.

Alexander, Christopher and Barry Poyner. "The Atoms of Environmental Structure.” Ed. G. Moore. Emerging Methods in Environmental Design and Planning. Cambridge, MA: MIT Press, 1970. 308-20.

Ambasz, Emilio. Italy: The New Domestic Landscape. New York: The Museum of Modern Art, 1972.

Aristotle. Politics. Mineola: Dover Publishing, 2012. 
Basso Peressut, Luca. “Interior Words.” Eds. L. Basso Peressut et al. Interior Wor(l)ds. Turin: Allemandi, 2010. 21-31.

Bauman, Zygmunt. Liquid Modernity. Cambridge, MA: Polity, 2000.

Benevolo, Leonardo. La città nella storia d'Europa. Rome-Bari: Laterza, 1993.

Carmona, Michel. Le mobilier urbain. Paris: PUF, 1985.

Choay, Françoise. La Règle et le Modèle: Sur la théorie de l'architecture et de l'urbanisme. Paris: Seuil., 1980.

---. Espacements: Figure di spazi urbani nel tempo. Milan: Skira, 2003.

Chombart de Lauwe, Paul-Henry. Paris et l'agglomeration parisienne. Paris: PUF, 1952.

Debord, Guy. “Critique de l’urbanisme.” Internationale situationniste 6 (1961): 7.

De Carli, Carlo. “Contro la realtà finta.” Interni 1 (1967): 3.

Gehl, Jan. Life between Buildings: Using Public Space. Skive: Arkitektens Forlag, 1971.

Giedion, Sigfried. The Human Scale: Advanced Seminar for the Master's Class. Cambridge, MA: Harvard GSD, 1959.

Gropius, Walter. Ein Versuchshaus des Bauhauses. München: Langen, 1924.

Hall, Edward T. The Hidden Dimension. New York: Doubleday, 1966.

Hertzberger, Herman. "Huiswerk voor meer herberzgame vorm.” Forum 3 (1973): 12-13.

Hillier, Bill and Julienne Hanson. The Social Logic of Space. Cambridge: Cambridge University Press, 1984.

Jacobs, Jane. The Death and Life of Great American Cities. New York: Vintage Books, 1961.

Jarvis, Robert. “Urban Environments as Visual Art or Social Setting.” Town Planning Review 51 (1980): 50-66.

Klanten, Robert, et al. Going Public: Public Architec_-Ture, Urbanism, and Interventions. Berlin: Gestalten, 2012.

Klanten, Robert and Martin Hübner. Urban Interventions: Personal Projects in Public Spaces. Berlin: Gestalten, 2010.

Leach, Neal. Digital Cities. London: Wiley, 2009.

Le Corbusier. “The Pack-Donkey’s Way and Man’s Way.” Eds. M. Larice and E. Macdonald. The Urban Design Reader. London: Routledge, 2007. 90-100.

Lefebvre, Henri. Le Droit à la ville. Paris: Anthropos, 1968.

Leveratto, Jacopo. "The Body Is the Medium (between Space and Technology)." International Journal of Interior Architecture+Spatial Design 2 (2014): 86-91.

---. "Planned to Be Reclaimed: Public Design Strategies for Spontaneous Practices of Spatial Appropriation.” Street Art \& Urban Creativity Scientific Journal 1 (2015): 6-12.

Lynch, Kevin. The Image of the City. Cambridge, MA: MIT Press, 1960.

---. The Good City Form. Cambridge, MA: MIT Press, 1981.

Mosco, Valerio Paolo. “Città e spazio pubblico.” XXI Secolo. Rome: Istituto dell’Enciclopedia Italiana, 2010. $179-84$.

Mumford, Lewis. The City in History. New York: Harcourt Brace and Jovanovich, 1961.

Neufert, Ernst. Bauentwurfslehre. Berlin: Bauwelt, 1936.

OMA, and Rem Koolhaas, and Bruce Mau. S, M, L, XL. New York: Monacelli Press, 1995.

Ratti, Carlo. Architettura Open Source: Verso una progettazione aperta. Turin: Einaudi, 2014.

Schmarsow, August. Das Wesen der architektonischen Schöpfung. Leipzig: Hiersemann, 1894.

Sert, Josep Lluis. “The Human Scale in City Planning.” Ed. P. Zucker. New Architecture and City Planning. New York: Philosophical Library, 1944. 392-413.

Simmel, Georg. The Metropolis and Mental Life. New York: Free Press, 1976.

Sitte, Camillo. Der Städtebau nach seinen künstlerischen Grundsätzen. Wien: Graeser, 1889.

Smithson, Alison and Peter. Urban Structuring. London: Studio Vista, 1957.

Sommer, Robert. "Studies in Personal Space.” Sociometry 22 (1959): 247-50.

Sorgel, Hermann. Einfuhrung in die Architektur Asthetik. Munchen: Piloty \& Loehle, 1918.

Spuybroek, Lars. “The Structure of Vagueness.” Textile 3 (2005): 6-19.

Teyssot, Georges. A Topology of Everyday Constellations. Cambridge, MA: MIT Press, 2013.

Tönnies, Ferdinand. Community and Civil Society. Cambridge: Cambridge University Press, 2001.

Van Eyck, Aldo. “Dutch Forum on Children’s Home.” Architectural Design 32 (1962): 602.

---. Writings: The Child, the City and the Artist. Amsterdam: SUN, 2008.

Vitruvius Pollio, Marcus. I dieci libri dell’Architettura, tradotti et commentati da Monsig. Daniel Barbaro. Venice, 1584.

Whyte, William H. The Social Life of Small Urban Spaces. New York: Project for Public Spaces, 1980. 